\title{
Barley responses to combined waterlogging and salinity stress: separating effects of oxygen deprivation and elemental toxicity
}

\author{
Fanrong Zeng ${ }^{1,2}$, Lana Shabala ${ }^{1}$, Meixue Zhou ${ }^{1}$, Guoping Zhang ${ }^{2}$ and Sergey Shabala ${ }^{1 *}$ \\ 1 School of Agricultural Science and Tasmanian Institute of Agriculture, University of Tasmania, Hobart, TAS, Australia \\ ${ }^{2}$ Department of Agronomy, College of Agriculture and Biotechnology, Zhejiang University, Hangzhou, China
}

\section{Edited by:}

Pierdomenico Perata, Scuola

Superiore Sant'Anna, Italy

\section{Reviewed by:}

Omar Pantoja, Universidad Nacional Autonoma de Mexico, Mexico

Stefano Mancuso, Università di

Firenze, Italy

\section{*Correspondence:}

Sergey Shabala, School of

Agricultural Science, University of

Tasmania, Private Bag 54, Hobart,

TAS 7001, Australia

e-mail: sergey.shabala@utas.edu.au
Salinity and waterlogging are two major factors affecting crop production around the world and often occur together (e.g., salt brought to the surface by rising water tables). While the physiological and molecular mechanisms of plant responses to each of these environmental constraints are studied in detail, the mechanisms underlying plant tolerance to their combined stress are much less understood. In this study, whole-plant physiological responses to individual/combined salinity and waterlogging stresses were studied using two barley varieties grown in either vermiculite (semi-hydroponics) or sandy loam. Two weeks of combined salinity and waterlogging treatment significantly decreased plant biomass, chlorophyll content, maximal quantum efficiency of PSII and water content (WC) in both varieties, while the percentage of chlorotic and necrotic leaves and leaf sap osmolality increased. The adverse effects of the combined stresses were much stronger in the waterlogging-sensitive variety Naso Nijo. Compared with salinity stress alone, the combined stress resulted in a 2-fold increase in leaf $\mathrm{Na}^{+}$, but a $40 \%$ decrease in leaf $\mathrm{K}^{+}$ content. Importantly, the effects of the combined stress were more pronounced in sandy loam compared with vermiculite and correlated with changes in the soil redox potential and accumulation of $\mathrm{Mn}$ and $\mathrm{Fe}$ in the waterlogged soils. It is concluded that hypoxia alone is not a major factor determining differential plant growth under adverse stress conditions, and that elemental toxicities resulting from changes in soil redox potential have a major impact on genotypic differences in plant physiological and agronomical responses. These results are further discussed in the context of plant breeding for waterlogging stress tolerance.

Keywords: salinity, waterlogging, microelement toxicity, barley, breeding, manganese, potassium, sodium

\section{INTRODUCTION}

Excessive soil salinization is a major ecological and agronomic problem throughout the world. According to the FAO Land and Plant Nutrition Management Service (2008), more than $800 \mathrm{Mha}$ of land throughout the world is affected by salinity, which accounts for over $6 \%$ of the world's total land area. Apart from natural salinity, secondary (human-induced) salinization of arable land has become a serious threat to agricultural production owing to improper cultivation practices and irrigation (Pannell and Ewing, 2004). Excessive quantities of ions (mainly $\mathrm{Na}^{+}$and $\mathrm{Cl}^{-}$) in the soil solution decrease soil osmotic potentials and the availability of water to plant roots. When accumulated in the shoot, these ions induce ion toxicity by disrupting the structure of enzymes, damaging cell organelles and interfering with cell metabolism (Maathuis and Amtmann, 1999). Salinity stress also results in significant ROS accumulation, both in roots (Xie et al., 2011) and leaves (Tanou et al., 2009), and interferes with $\mathrm{K}^{+}$ homeostasis (Maathuis and Amtmann, 1999; Shabala and Cuin, 2008), triggering accelerated cell death (Shabala, 2009; Joseph and Jini, 2010).
Waterlogging occurs over a vast region of the world, adversely affecting about $10 \%$ of the global land area (Setter and Waters, 2003) and reducing crop yields by as much as $80 \%$ (Shabala, 2011). Under waterlogging condition, soil gas exchange is severely impeded. This results in a significant depletion of free oxygen $\left(\mathrm{O}_{2}\right)$ and accumulation of carbon oxide $\left(\mathrm{CO}_{2}\right)$ due to microbial and root respiration (Bailey-Serres and Voesenek, 2008). As soon as the free $\mathrm{O}_{2}$ surrounding the roots is depleted, hypoxia stress occurs, causing a transfer from aerobic to anaerobic metabolism in roots, with dramatic restrictions to ATP synthesis (Barrett-Lennard, 2003; Teakle et al., 2006). Waterlogging also causes a sharp decrease in the soil redox potential, resulting in very significant changes to the soil chemical profile. Effects include a changed availability of mineral substances, reduction of manganese $\left(\mathrm{Mn}^{4+}\right)$, iron $\left(\mathrm{Fe}^{3+}\right)$, and sulfate $\left(\mathrm{SO}_{4}^{2-}\right)$, increased solubility of potentially toxic metals and production of toxic compounds by plant roots and microbial anaerobic metabolism (Kozlowski, 1997; Shabala, 2011). As a consequence of these changes, plants show altered membrane transport, decreased stomatal conductance and leaf water potentials, enhanced root 
senescence, reduced root and shoot growth, and eventually, death of the whole plant (Barrett-Lennard, 2003).

In recent years, an impressive amount of knowledge has accumulated on plant physiological and molecular responses to salinity or waterlogging stresses. However, studies dealing with the combined effects of these two stresses are much rarer and often controversial [reviewed by Barrett-Lennard (2003)]. Nonetheless, the occurrence of combined salinity and waterlogging stress is increasing throughout the world This is due to intensive irrigation in agricultural production systems (Smedema and Shiati, 2002), rise of saline water tables (Hatton et al., 2003), and seawater intrusion in coastal environments (Carter et al., 2006). When combined with waterlogging, salinity can cause even greater damage to plants, so having a major impact on agricultural production (Barrett-Lennard, 2003). Only a very few crop species can tolerate the combination of salinity and waterlogging (Bennett et al., 2009), and the physiological and molecular mechanisms conferring this tolerance remain elusive.

Barley (Hordeum vulgare L.) is one of the most important crop species in the world. Barley is tolerant to salinity (Chen et al., 2007), so is a good candidate for use in saline discharge areas. However, barley is sensitive to waterlogging (Zhou et al., 2012), and the co-occurrence of waterlogging with salinity may seriously decrease this potential. In this study, the physiological and ionic characteristics of two contrasting barley varieties, grown in two soil types, were investigated in response to combined salinity and waterlogging stress. Our results suggest that hypoxia is not the only factor affecting plant growth under adverse stress conditions and that elemental toxicities resulting from changes in the soil redox potential has a major impact on genotypic differences in plant physiological and agronomical responses.

\section{MATERIALS AND METHODS}

\section{PLANT MATERIALS AND GROWTH CONDITIONS}

Two barley (Hordeum vulgare L.) varieties contrasting in both waterlogging and salinity tolerance (CM72, tolerant to salinity and with medium tolerance to waterlogging, and Naso Nijo, sensitive to both waterlogging and salinity; Chen et al., 2007; Pang et al., 2007), were used in this work. Seeds were obtained from the Australian Winter Cereal Collection and multiplied using the TIA facilities in Launceston. Seeds were surface sterilized with $10 \%$ commercial bleach ( $\mathrm{NaClO} 42 \mathrm{~g} / \mathrm{L}$, Pental Products, Shepparton, Australia), thoroughly rinsed with tap water, then sown at a $10 \mathrm{~mm}$-depth in $2 \mathrm{~L}$-pots. Two different types of growth mediasandy loam and vermiculite-were used. Sandy loam soil, which was taken from the University of Tasmania farm near Cambridge in southeast Tasmania, was first air-dried and then sieved through a $5 \mathrm{~mm}$ sieve. The soil was fertilized by adding all the essential macronutrients at the optimal field application rates, taking into account the pot factor (in g/10 L: $5.13 \mathrm{NH}_{4} \mathrm{NO}_{3}, 13.57 \mathrm{NaH}_{2} \mathrm{PO}_{4}$, $4.88 \mathrm{~K}_{2} \mathrm{SO}_{4}, 3.1 \mathrm{CaSO}_{4}$, and $1.42 \mathrm{MgCl}_{2}$ ) and watered to field capacity with tap water during the experiment. Plants grown in vermiculite were watered with half-strength Hoagland's nutrient solution. After germination, barley seedlings were thinned to 10 uniform and healthy plants in each pot. Plants were grown under controlled glasshouse condition (with a day-length of $14 \mathrm{~h}$; light/dark temperatures, $25 / 15^{\circ} \mathrm{C}$; and relative humidity, $65 \%$ ) at the University of Tasmania (Hobart, Australia). The experiment was repeated twice in April and June 2012.

Treatments were imposed when plants were at the fully expanded first leaf stage $(\sim 1$ week old). For treatments with waterlogging, pots were placed into large black tanks (6 pots in each tank). Four treatments were given: control (no $\mathrm{NaCl}$; well drained), salinity (referred as "NaCl"; well drained pots watered with $200 \mathrm{mM} \mathrm{NaCl}$ solution), waterlogging ("WL"; submerged pots; no $\mathrm{NaCl}$ ) and combined waterlogging and salinity ("NaCl/WL"; pots submerged in $200 \mathrm{mM} \mathrm{NaCl}$ solution). Waterlogged conditions were created by using either tap water or half-strength Hoagland's nutrient solution, depending on the soil type (i.e., whether sandy loam or vermiculate). The entire

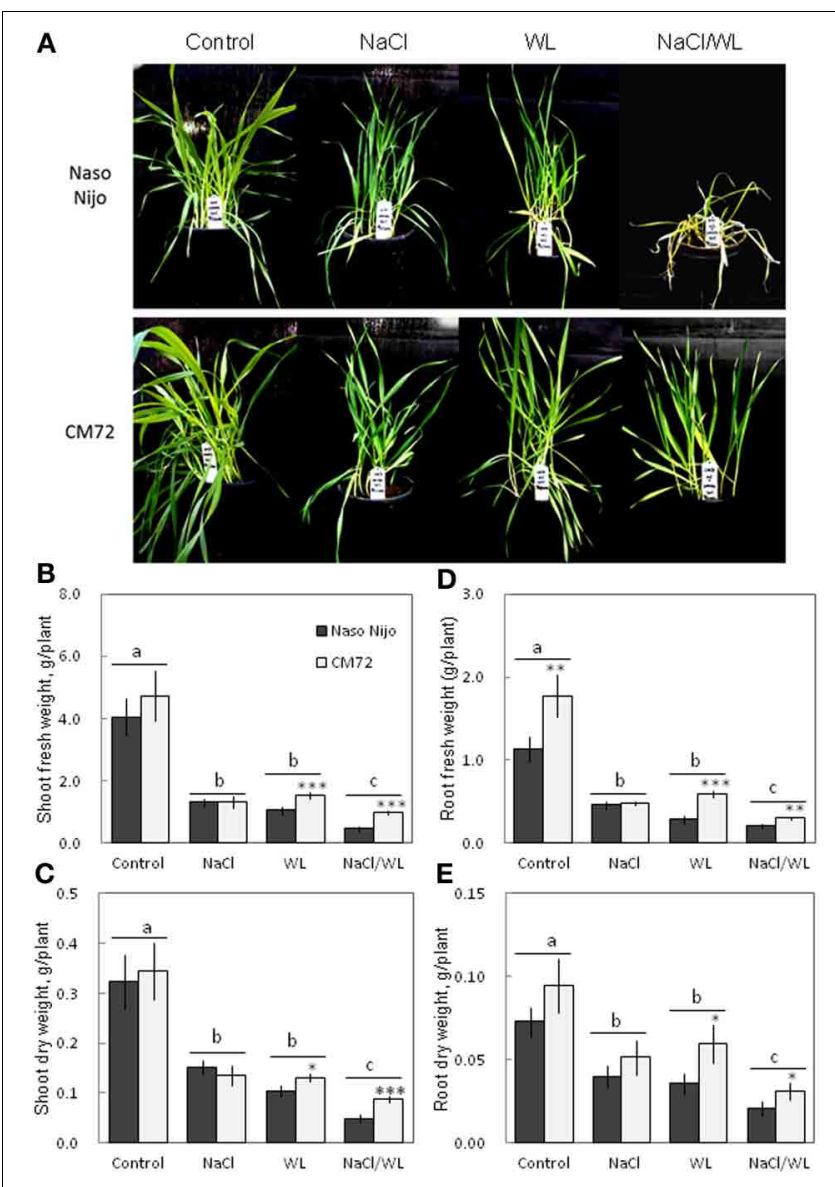

FIGURE 1 | Effects of separate and combined salinity and waterlogging stresses on growth of two contrasting barley cultivars in sandy loam. Dark bars, Naso Nijo; light bars, CM72. One-week old barley seedlings were subjected to one of four treatments: Control (no NaCl; well drained), $\mathrm{NaCl}$ (well-drained pots watered with $200 \mathrm{mM} \mathrm{NaCl}$ solution), WL (submerged pots; no $\mathrm{NaCl}$ ), $\mathrm{NaCl} / \mathrm{WL}$ (pots submerged in $200 \mathrm{mM} \mathrm{NaCl}$ solution). Plants were harvested for morphological (A) and biomass analysis (B-E) 14 days after the onset of treatment. For growth condition and media composition, refer to the Materials and Methods section. Mean $\pm \mathrm{SD}$ $(n=5)$. Different lower case letters indicate the significant difference between treatments (averaged for both genotypes) at $P<0.01$. Asterisks indicate the significant difference between cultivars within treatment at ${ }^{*} P<0.01,{ }^{* *} P<0.001$, and ${ }^{* * *} P<0.0001$ 
experiment was carried out in a split-plot design with tanks as the main plots and barley varieties as subplots. Six replicates were set up for each treatment $\times$ variety combination.

Daily irrigation for drained treatments was artificially maintained with the same amount $(150 \mathrm{~mL})$ of different solutions, as described above. The water level of waterlogged treatments was kept $15 \mathrm{~mm}$ above the soil surface. Plants were subjected to different treatments for 14 days, after which the genotypic variance was clearly distinguished visually. The seedlings were then sampled randomly for the following analyses.

\section{SPAD AND CHLOROPHYLL FLUORESCENCE}

Leaf chlorophyll content and chlorophyll fluorescence were measured on the middle part of the oldest fully expanded leaves

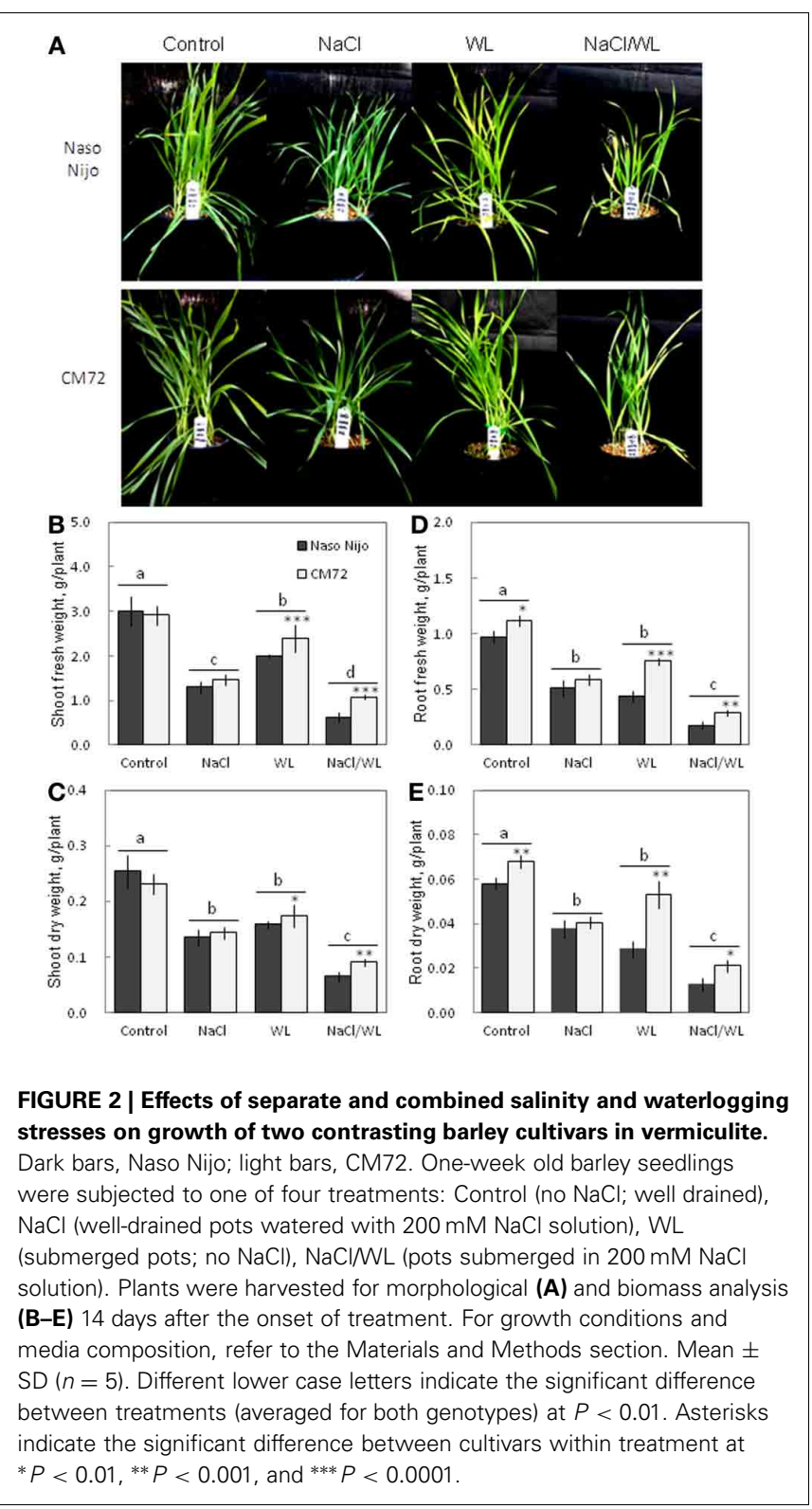

(which had been subjected to the treatment for a full 2 weeks), prior to sampling for other parameters. Leaf chlorophyll content was measured with a SPAD meter (SPAD-502, MINOLTA, Japan). Chlorophyll fluorescence was measured with a OS-30p chlorophyll fluorometer (OPTI-Sciences, Hudson, USA). Plants were dark-adapted for $30 \mathrm{~min}$ prior to measurement. The maximum quantum efficiency of photosystem II $\left(F \mathrm{v} / F \mathrm{~m}=\left(F \mathrm{~m}-F_{\mathrm{o}}\right) / F \mathrm{~m}\right)$ was recorded at a saturating actinic light $(660 \mathrm{~nm})$ intensity of $1100 \mu \mathrm{mol} / \mathrm{m}^{2} / \mathrm{s}$. Twelve replicates were randomly taken for each treatment $\times$ variety combination.

\section{RATIO OF CHLOROTIC AND NECROTIC LEAVES}

Prior to harvest for biomass, the number (no.) of chlorotic, necrotic, and total leaves from each plant were counted. The ratio of chlorotic (or necrotic) leaves was then calculated according to the equation: ratio of chlorotic (or necrotic) leaves $=$ no. of chlorotic (/necrotic) leaves/no. of total leaves. Twelve replicates were randomly taken for each treatment $x$ variety combination.

\section{BIOMASS}

For harvesting, plant roots were gently washed with running tap water, rinsed with distilled water, then blotted dry with soft tissue. Five replicates were taken for each treatment $\times$ variety combination, and three plants were bulked together for each replicate. The fresh weights of shoots and roots were measured as soon as the seedlings were separated and the dry weights were measured after drying in a Unitherm Drier (Birmingham, England) for 2 days at $65^{\circ} \mathrm{C}$.

\section{LEAF WATER CONTENT}

Leaf fresh and dry weights were used to calculate the leaf water content (WC) on a fresh weight basis using the following equation: $\mathrm{WC} \%=($ fresh weight - dry weight $) /$ fresh weight $\times 100 \%$. Fresh leaf blades of whole seedlings were collected and weighed immediately for their fresh weights. Dry weights were determined after drying for 2 days at $65^{\circ} \mathrm{C}$. Five replicates were taken for each treatment $\times$ variety combination.

\section{NA+ AND $\mathrm{K}^{+}$CONTENTS AND OSMOLALITY IN PLANT TISSUE}

$\mathrm{Na}^{+}$and $\mathrm{K}^{+}$contents were determined from the leaf and root sap. After harvesting as described above, plant roots and the oldest fully expanded leaves, which had been subjected to the treatment for a full 2 weeks, were collected and immediately stored in a $1.5 \mathrm{ml}$ microcentrifuge tube at $-20^{\circ} \mathrm{C}$. Five replicates were taken for each treatment $\times$ variety combination. The sap from roots and leaves was extracted by the freeze-thaw method (Cuin et al., 2008). After centrifuged at $10,000 \mathrm{~g}$ for $3 \mathrm{~min}$, the extracted sap sample was diluted 500 times with double distilled water and analyzed for its $\mathrm{Na}$ and $\mathrm{K}$ content using a flame photometer (PF97, VWR International, Murarrie, Australia).

The extracted leaf sap was also analyzed for its osmolality using a vapor pressure osmometer (Vapro, Wescor Inc. Logan, Utah, USA).

\section{ROOT ATP CONTENT}

Two weeks after commencing treatments, roots were harvested for ATP extraction according to a modified method of Yang 
et al. (2002). Briefly, $0.2 \mathrm{~g}$ of liquid nitrogen-homogenized root powder was rapidly mixed with $0.5 \mathrm{~mL} 0.0005 \%$ (v/v) $\mathrm{HCl}_{4}$ and heated in a boiling water bath for $10 \mathrm{~min}$. After cooling on ice, the extraction mixture was centrifuged for $5 \mathrm{~min}$ at $10,000 \times \mathrm{g}$ at $4^{\circ} \mathrm{C}$. The supernatant was used for the ATP assay. The ATP content was quantified using the ATP Colorimetric Assay Kit (ab83355, ABCAM, Cambridge, UK) with a microplate reader (SPECTROstar Nano, BMG LABTECH, Mornington, Australia). The reaction mix contained $4 \%(\mathrm{v} / \mathrm{v})$ ATP probe, 4\% (v/v) ATP converter and 4\% (v/v) developer in the ATP Assay Buffer (ab83355, ABCAM, Cambridge, UK). ATP standards (0-5 nmol range) and extracted samples were placed into a 96-well plate. The reaction mix was added at $1: 1(\mathrm{v} / \mathrm{v})$ ratio, and plates were incubated at the room temperature in the dark for $30 \mathrm{~min}$. The extraction solution without root tissue was used as a negative control. ATP concentrations in the samples were calculated by plotting the measured absorbance at $570 \mathrm{~nm}\left(\mathrm{OD}_{570 \mathrm{~nm}}\right)$ vs. the standard linear curve.

\section{NET ION FLUXES FROM THE ROOT EPIDERMIS}

Net $\mathrm{K}^{+}$and $\mathrm{H}^{+}$fluxes were measured from the root epidermis of barley seedlings using non-invasive ion-selective vibrating microelectrodes (the MIFE technique, University of Tasmania, Hobart, Australia), essentially as described in our previous publications (Chen et al., 2007; Cuin et al., 2008). Barley seedlings were grown in an aerated Basic Salt Media (BSM) solution $\left(0.5 \mathrm{mM} \mathrm{KCl}+0.1 \mathrm{mM} \mathrm{CaCl}_{2}, \mathrm{pH} 5.6\right)$ in the dark for 3 days at room temperature $\left(25 \pm 1^{\circ} \mathrm{C}\right)$. At that stage, $1 \mathrm{mM} \mathrm{MnCl}_{2}$ was added to the BSM, and plants were grown for up to 3 more days in the presence of $\mathrm{Mn}$. Roots of intact seedlings were mounted in a $10 \mathrm{~mL}$ perspex measuring chamber filling with the appropriate solution (BSM for control; $\mathrm{BSM}+1 \mathrm{mM} \mathrm{MnCl}_{2}$ for $\mathrm{Mn}$ treatment) $1 \mathrm{~h}$ prior to measurement. Ion-selective microelectrodes were position $40 \mu \mathrm{m}$ above the root surface, with their tips separated by ca. $2 \mu \mathrm{m}$. Ion fluxes were measured by a slow (5 s half-cycle) square-wave movement of electrodes between two positions, close to $(40 \mu \mathrm{m})$ and away from $(80 \mu \mathrm{m})$ the root surface. Net ion fluxes were measured from the mature root epidermis $\sim 20 \mathrm{~mm}$ from the root tip. The potential difference between two positions was recorded by the MIFE CHART software and converted to the electrochemical potential difference using the calibrated Nernst slope of the electrodes. Net ion fluxes were calculated from the electrochemical potential difference using cylindrical diffusion geometry by the MIFEFLUX program. Net ion fluxes were measured for $10 \mathrm{~min}$, and the
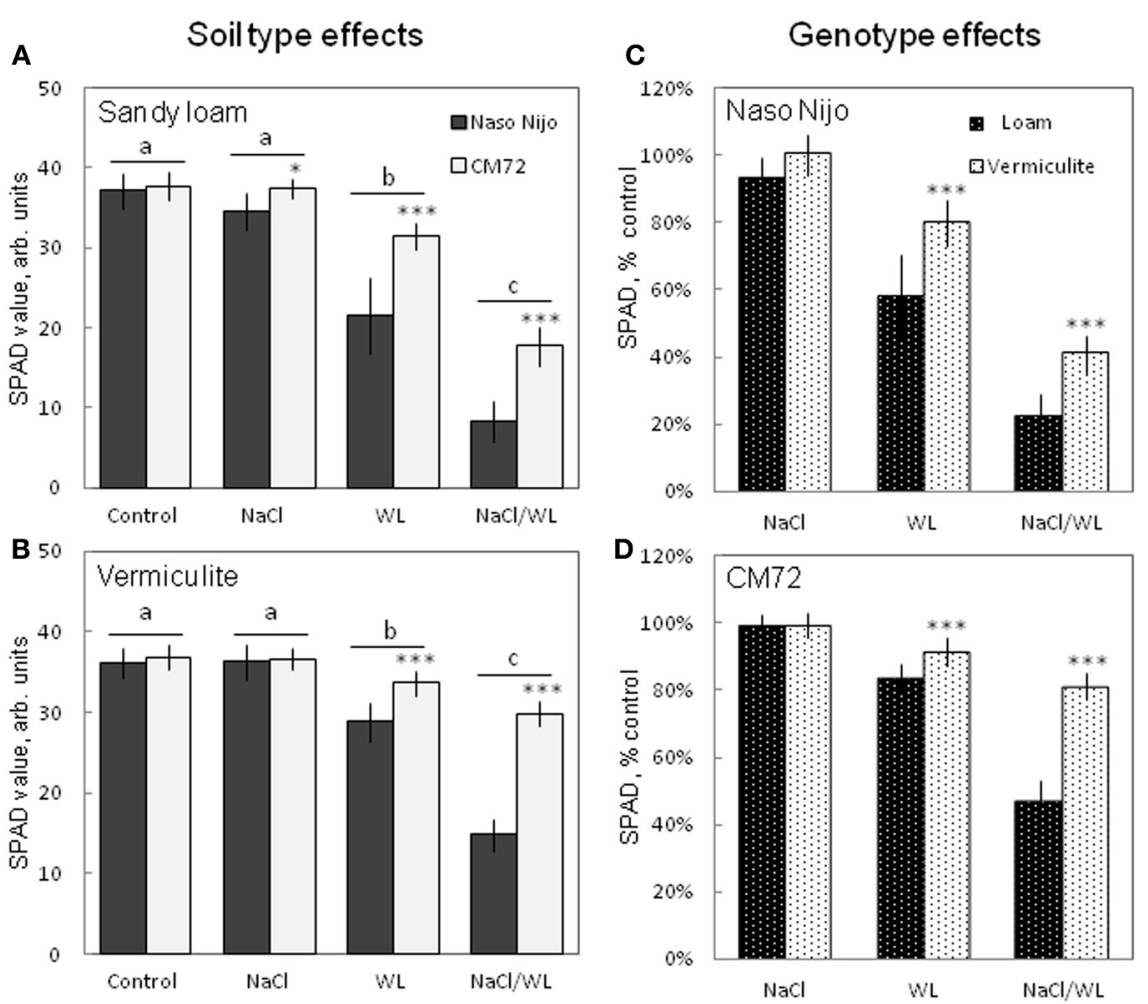

FIGURE 3 | Effects of separate and combined salinity and waterlogging stresses on chlorophyll content (SPAD values) of two contrasting barley cultivars. Measurements were taken 14 days after the onset of treatment. (A,B) Soil type effects. Dark bars, Naso Nijo; light bars, CM72. (C,D) Genotype effects. Dark bars, sandy loam; light bars, vermiculite. For growth conditions, details of

treatments, and media composition, refer to the Materials and Methods section. Mean $\pm \operatorname{SD}(n=12)$. Different lower case letters indicate the significant difference between treatments (averaged for both genotypes) at $P<0.01$. Asterisks indicate the significant difference between cultivars within the treatment at ${ }^{*} P<0.01$ and *** $P<0.0001$. 
steady-state fluxes were calculated by averaging the values over the last $5 \mathrm{~min}$.

\section{SOIL REDOX POTENTIAL}

Soil redox potential (or oxidation-reduction potential, ORP) was measured using an ORP electrode connected to a Handheld Multi-Parameter (LabNavigator, Forston Labs, Colorado, USA) before treatment ("drained control"), and after 3 and 14 days of waterlogging, both in the presence and absence of $\mathrm{NaCl}$. To measure the ORP for drained controls, a $5 \mathrm{~cm}$-deep hole was dug in the soil and the ORP electrode was carefully placed in the hole with the diaphragm touching the humid soil surface. All measurements were taken as close to roots as practically possible, without causing any damage. Each measurement was recorded for $180 \mathrm{~s}$ with one reading per second, and a reliable ORP value was achieved by averaging the readings from the last $120 \mathrm{~s}$. These measurements were conducted about $1 \mathrm{~h}$ after watering.

\section{Fe AND Mn CONCENTRATIONS IN THE SOIL SOLUTION}

Soil solutions for determining Fe and Mn concentrations were sampled at the time of ORP measurement. For the WL and $\mathrm{NaCl} / \mathrm{WL}$ treatments, soil solution was taken from five spots for each container, and combined into one collective sample for $\mathrm{Fe}$ and $\mathrm{Mn}$ determination. To determine Fe and Mn concentrations in the drained controls, a 1:2.5 (v/v) soil:solution mix was made (using tap water for clay, and $1 / 2$ Hoagland nutrient solution for vermiculite), stirred for $30 \mathrm{~min}$ at room temperature, then decanted. All samples were then filtered, and Fe and Mn concentrations were determined using the Atomic Absorption Spectroscopy (AAS) technique (Avanta $\Sigma$, GBC Scientific Equipment, Braeside, Australia). Five replicates of collective samples were taken for each treatment.

\section{STATISTICAL ANALYSIS}

Statistical analysis was performed by the statistical package, IBM SPSS Statistics 20 (IBM, New York, USA). All data in the figures and tables are given as means \pm SD. The Multivariate General Linear Model was used to confirm the significance of the factors (soil types, treatments, and varieties). Significant differences between treatments on the mean of the two varieties were compared using Duncan's multiple range tests.

\section{RESULTS}

\section{PLANT GROWTH}

Plant growth was significantly reduced by all stress treatments (Figures 1, 2). The combined $\mathrm{NaCl} / \mathrm{WL}$ treatment showed the most severe effect on plant growth. When grown in sandy loam, the average shoot FW and DW of the two varieties treated by $\mathrm{NaCl} / \mathrm{WL}$ were reduced by 81 and $76 \%$ relative to the control, respectively, with the corresponding values for roots being 85
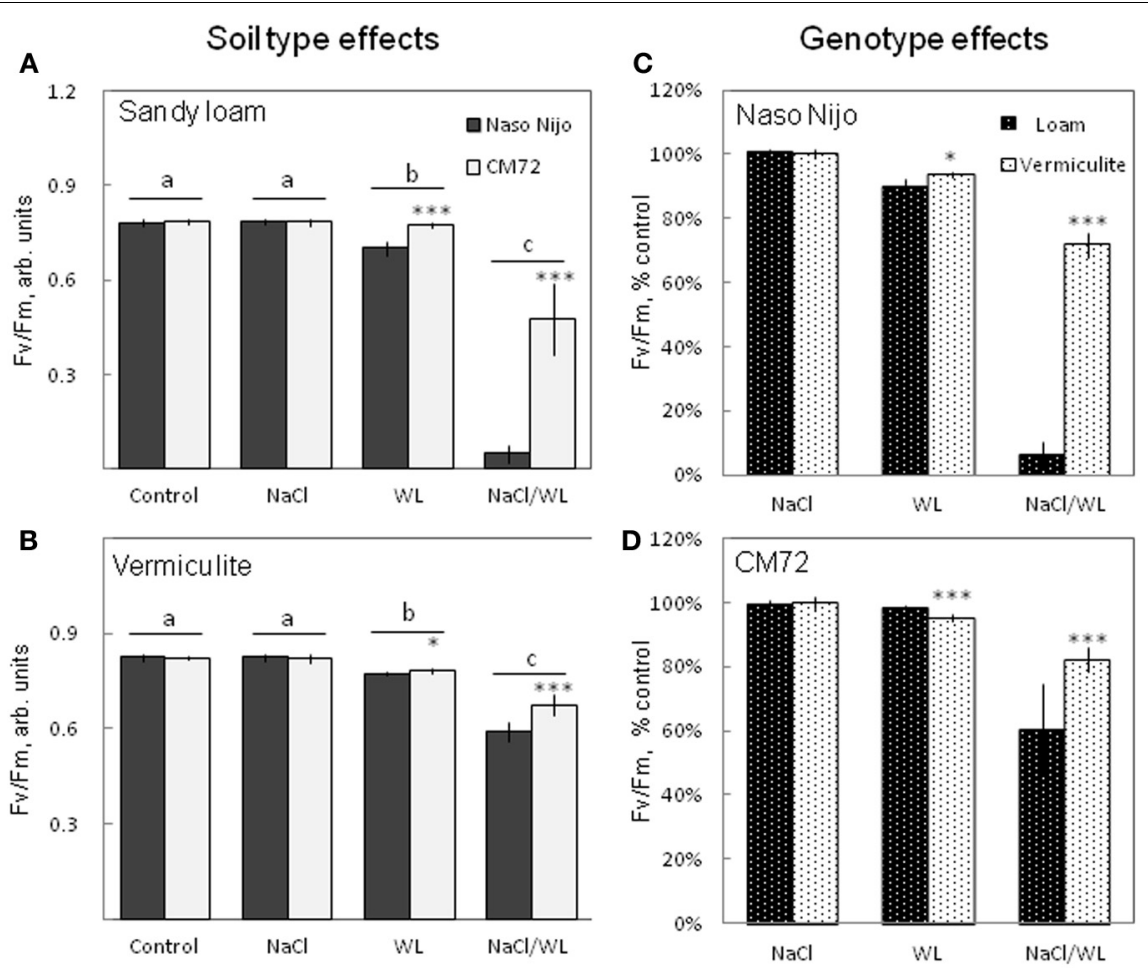

FIGURE 4 | Effects of separate and combined salinity and waterlogging stresses on maximum photochemical efficiency of PSII (Fv/Fm chlorophyll fluorescence values) of two contrasting barley cultivars. Measurements were taken 14 days after the onset of treatment. (A,B) Soil type effects. Dark bars, Naso Nijo; light bars, CM72. (C,D) Genotype effects. Dark bars, sandy loam; light bars, vermiculite. For growth conditions, details of treatments, and media composition, refer to the Materials and Methods section. Mean $\pm \mathrm{SD}$ $(n=12)$. Different lower case letters indicate the significant difference between treatments (averaged for both genotypes) at $P<0.01$. Asterisks indicate the significant difference between cultivars within the treatment at $* P<0.01$ and ${ }^{* * *} P<0.0001$. 
and $77 \%$ (Figures 1B-E). Plants grown in vermiculite performed better under combined $\mathrm{NaCl} / \mathrm{WL}$ treatment, with a 71 and $32 \%$ reduction in the shoot $\mathrm{FW}$ and DW and 78 and $73 \%$ reduction in root FW and DW, respectively (Figures 2B-E). The genotypic difference in tolerance to the combined stress was clearly visible when plants were grown in sandy loam. After 14 days of $\mathrm{NaCl} / \mathrm{WL}$ treatment, most Naso Nijo plants had died, and the plant FW was only $12 \%$ of that of control (Figures 1A,C). However, in the CM72 plants, only some moderately stressed symptoms were observed and $25 \%$ FW of the control was maintained.

\section{CHLOROPHYLL CONTENT AND FLUORESCENCE}

After 2 weeks of treatment, $\mathrm{NaCl}$ alone had no significant (at $P<0.01$ ) effect on the leaf chlorophyll content (SPAD value) for either variety grown in either growth media. However, WL and $\mathrm{NaCl} / \mathrm{WL}$ treatments caused a massive reduction in the chlorophyll content (Figure 3) in both varieties. Sandy loam-grown plants were affected more than plants grown in vermiculite (ca. 40\% more reduction in $\mathrm{NaCl} / \mathrm{WL}$ treatment, Figures 3C,D). The combined $\mathrm{NaCl} / \mathrm{WL}$ treatment was more detrimental compared with WL alone in both varieties (Figures 3A,B). The observed decline in chlorophyll content was genotype-specific, with chlorophyll content in CM72 plants being significantly higher than that in Naso Nijo plants for each treatment, except for the control (Figures 3A,B).

The maximum photochemical efficiency of PSII (chlorophyll fluorescence $F \mathrm{v} / F \mathrm{~m}$ value) was also significantly affected by WL and $\mathrm{NaCl} / \mathrm{WL}$ treatments (Figure 4). A substantial decline in $\mathrm{Fv} / F \mathrm{~m}$ value was reported for both treatments (Figures 4A,B). None of these parameters, however, was affected by $\mathrm{NaCl}$ alone (at $P<0.01$, Figures $4 \mathrm{~A}, \mathrm{~B}$ ). On averaging the two varieties, the effect of the combined $\mathrm{NaCl} / \mathrm{WL}$ stress was much more severe than WL alone (at $P<0.01$, Figures 4A,B). CM72 plants were less sensitive to both $\mathrm{WL}$ and combined $\mathrm{NaCl} / \mathrm{WL}$ stresses than Naso Nijo (Figures 4A,B). Stress effects were strongly influenced by the growth conditions (sandy loam vs. vermiculite), with a much stronger decline in $\mathrm{Fv} / \mathrm{Fm}$ observed in sandy loam-grown plants $(66 \%$ more reduction for Naso Nijo and $22 \%$ more for CM72 under sandy loam conditions than those grown in vermiculite, Figures 4C,D).

\section{LEAF CHLOROSIS AND NECROSIS}

Leaf chlorosis and necrosis are important visible symptoms associated with abiotic stresses. As shown in Figure 5, leaf chlorosis and necrosis were induced by WL treatment and exacerbated by the combined $\mathrm{NaCl} / \mathrm{WL}$ stress. Variety CM72 performed much better compared with Naso Nijo. As such, no chlorotic or necrotic leaves were present in CM72 plants under WL treatment, while a substantial percentage of Naso Nijo leaves were affected by WL (Figure 5A). Under combined $\mathrm{NaCl} / \mathrm{WL}$ stress, half the CM72 leaves showed visual stress symptoms, while in the more sensitive Naso Nijo, over $90 \%$ leaves were either chlorotic or nectrotic (Figure 5A). Visual stress symptoms were more pronounced in the sandy loam-grown plants (Figure 5A) compared with

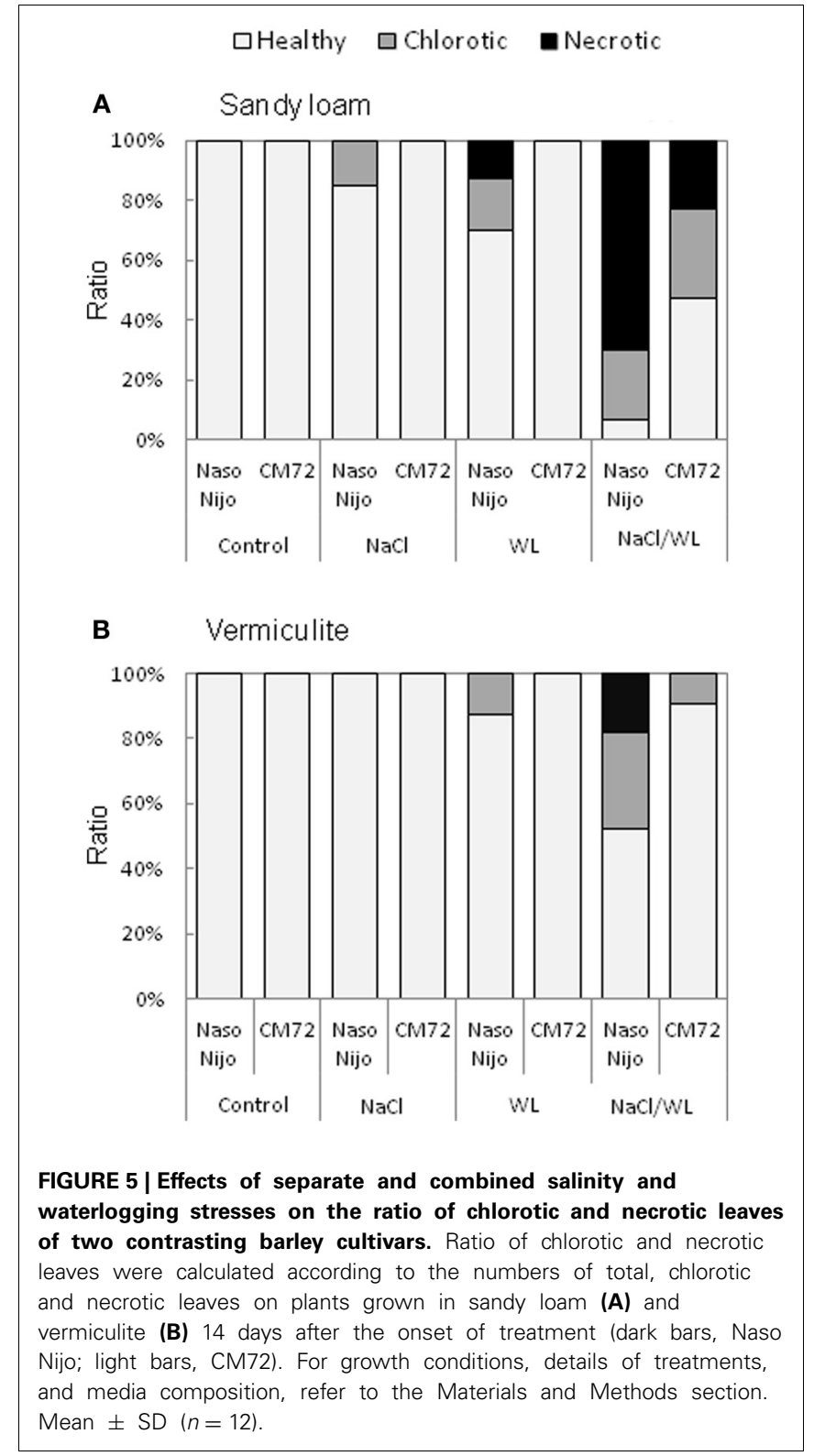

those grown in vermiculate (Figure 5B). Taking the combined $\mathrm{NaCl} / \mathrm{WL}$ treatment as an example, Naso Nijo had over $70 \%$ necrotic leaves when grown in sandy loam but only $18 \%$ in vermiculite; for CM72 the corresponding values were 22 and $0 \%$ (Figure 5).

\section{LEAF WATER CONTENT AND SAP OSMOLALITY}

Leaf WC was significantly decreased by $\mathrm{NaCl}$ and $\mathrm{NaCl} / \mathrm{WL}$ treatments under both growth conditions (Figure 6). At the same time, WL treatment did not significantly affect leaf WC under sandy loam conditions (at $P<0.01$, Figure 6A), and even slightly increased leaf WC in plants grown in vermiculite (Figure 6B). A significant (at $P<0.01$ ) difference in leaf WC between the contrasting varieties was observed for each treatment except the control in this experiment (Figures 6A,B). The growth conditions 


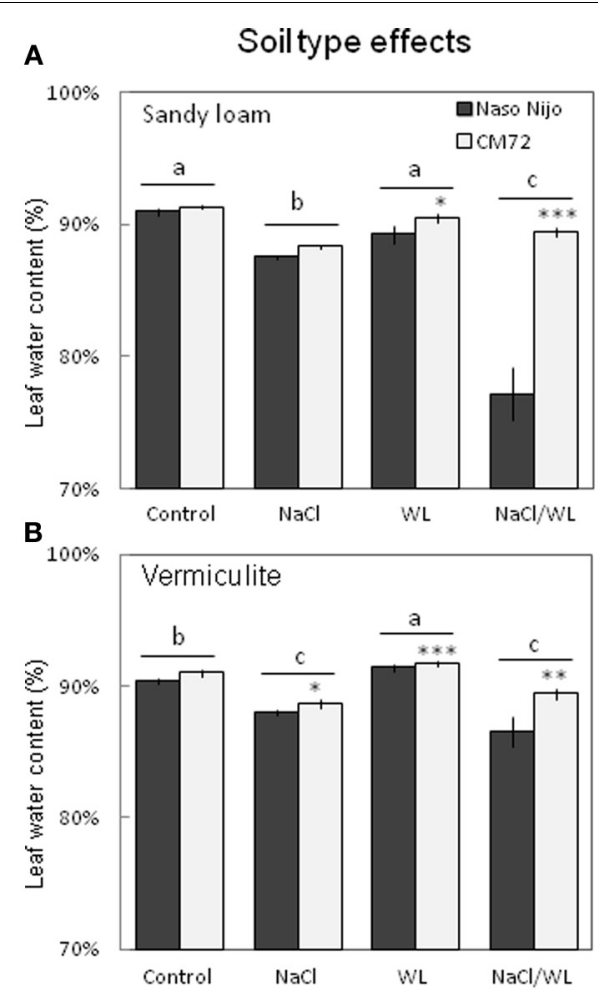

FIGURE 6 | Effects of separate and combined salinity and waterlogging stresses on leaf water content of two contrasting barley cultivars. (A,B) Soil type effects. Dark bars, Naso Nijo; light bars, CM72. (C,D) Genotype effects. Dark bars, sandy loam; light bars, vermiculite. For growth conditions, details of treatments, and media composition, refer to

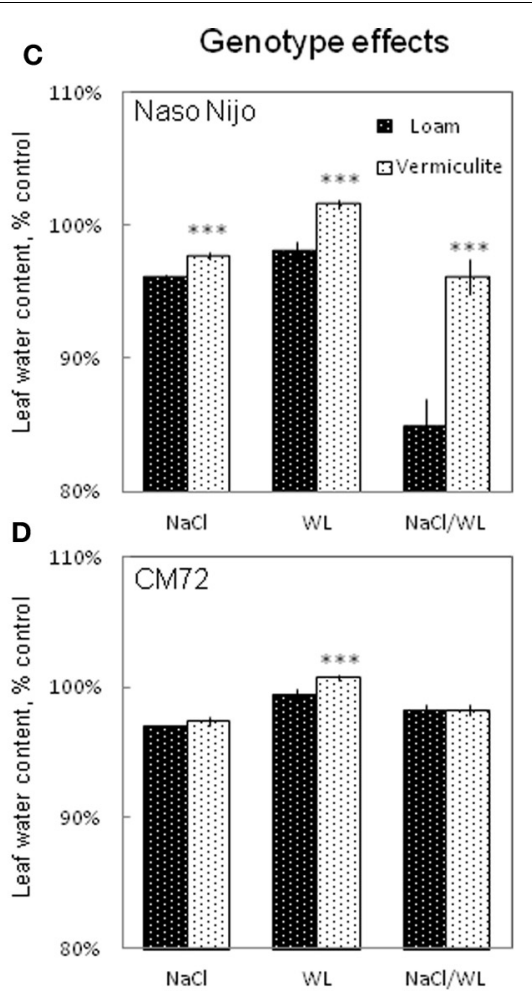

the Materials and Methods section. Mean \pm SD $(n=5)$. Different lower case letters indicate the significant difference between treatments (averaged for both genotypes) at $P<0.01$. Asterisks indicate the significant difference between cultivars within the treatment at $* P<0.01$, ** $P<0.001$, and $* * * P<0.0001$. (sandy loam vs. vermiculite) showed a significant impact on leaf WC, but only in the sensitive variety Naso Nijo (Figures 6C,D).

To a large extent, changes in the leaf WC were mirrored by changes in leaf sap osmolality (Figure 7). Much higher leaf sap osmolality (significant at $P<0.01$ ) was measured in plants grown in the presence of $\mathrm{NaCl}$ (i.e., in both $\mathrm{NaCl}$ and $\mathrm{NaCl} / \mathrm{WL}$ treatments), while no significant change in leaf osmolality was found for WL treatment as compared to the control. The combination of waterlogging and salt stress not only induced a massive increase in leaf sap osmolality, but also allowed a clear differentiation between the contrasting varieties, with about a 2-fold difference (significant at $P<0.001$ ) between them (Figures 7A,B). No significant (at $P<0.01$ ) effect of growth media (sandy loam vs. vermiculate) on leaf sap osmolality was found (Figures 7C,D).

\section{SAP $\mathrm{Na}^{+}$AND $\mathrm{K}^{+}$CONTENTS}

As expected, $\mathrm{NaCl}$ treatment caused dramatic increases in the $\mathrm{Na}^{+}$content (Figure 8) but a decrease in the $\mathrm{K}^{+}$content (Figure 9) for both the leaf and root (at $P<0.01$ ). Compared with $\mathrm{NaCl}$ alone, the combined $\mathrm{NaCl} / \mathrm{WL}$ treatment further increased the leaf $\mathrm{Na}^{+}$content (about a 1.7-2-fold increase on average of the two varieties, Figures $8 \mathbf{A}, \mathbf{B}$ ), but decreased leaf $\mathrm{K}^{+}$content (about 27 to $44 \%$ decrease on average of the two varieties, Figures 9A,B). However, the combined $\mathrm{NaCl} / \mathrm{WL}$ treatment did not cause further changes to root $\mathrm{Na}^{+}$(Figures 8C,D) and $\mathrm{K}^{+}$(Figures 9C,D) contents. WL treatment induced a significant decrease in leaf $\mathrm{K}^{+}$content and a significant increase in root $\mathrm{K}^{+}$content (at $P<0.01$, Figure 9) as compared to control, while no significant change was found in $\mathrm{Na}^{+}$content (at $P<0.01$, Figure 8). A clear differentiation in $\mathrm{Na}^{+}$and $\mathrm{K}^{+}$contents between the contrasting varieties appeared under the combined $\mathrm{NaCl} / \mathrm{WL}$ treatment. Relative to Naso Nijo, the tolerant variety CM72 had a $27-33 \%$ lower $\mathrm{Na}^{+}$content (at $P<0.01$, Figures 8A,B) and $77-88 \%$ higher $\mathrm{K}^{+}$content (at $P<0.0001$, Figures 9A,B) in leaves. For roots, the corresponding values were $15-18 \%$ (at $P<0.0001$, Figures 8C,D) and 94-150\% (at $P<0.0001$, Figures 9C,D). The growth conditions (sandy loam vs. vermiculite) showed a significant impact on both $\mathrm{Na}^{+}$and $\mathrm{K}^{+}$contents. The vermiculite-grown plants contained much more $\mathrm{Na}^{+}$and $\mathrm{K}^{+}$in both the leaves and roots compared to those grown in sandy loam under saline conditions (both $\mathrm{NaCl}$ and $\mathrm{NaCl} / \mathrm{WL}$ treatments) (Figures 8, 9). Taking CM72 in the combined $\mathrm{NaCl} / \mathrm{WL}$ treatment as an example, plants grown in vermiculite had a 54\% higher leaf $\mathrm{Na}^{+}$and $32 \%$ higher root $\mathrm{Na}^{+}$contents than in sandy loam (Figure 8). For $\mathrm{K}^{+}$, the corresponding values were 50 and $27 \%$ (Figure 9). 

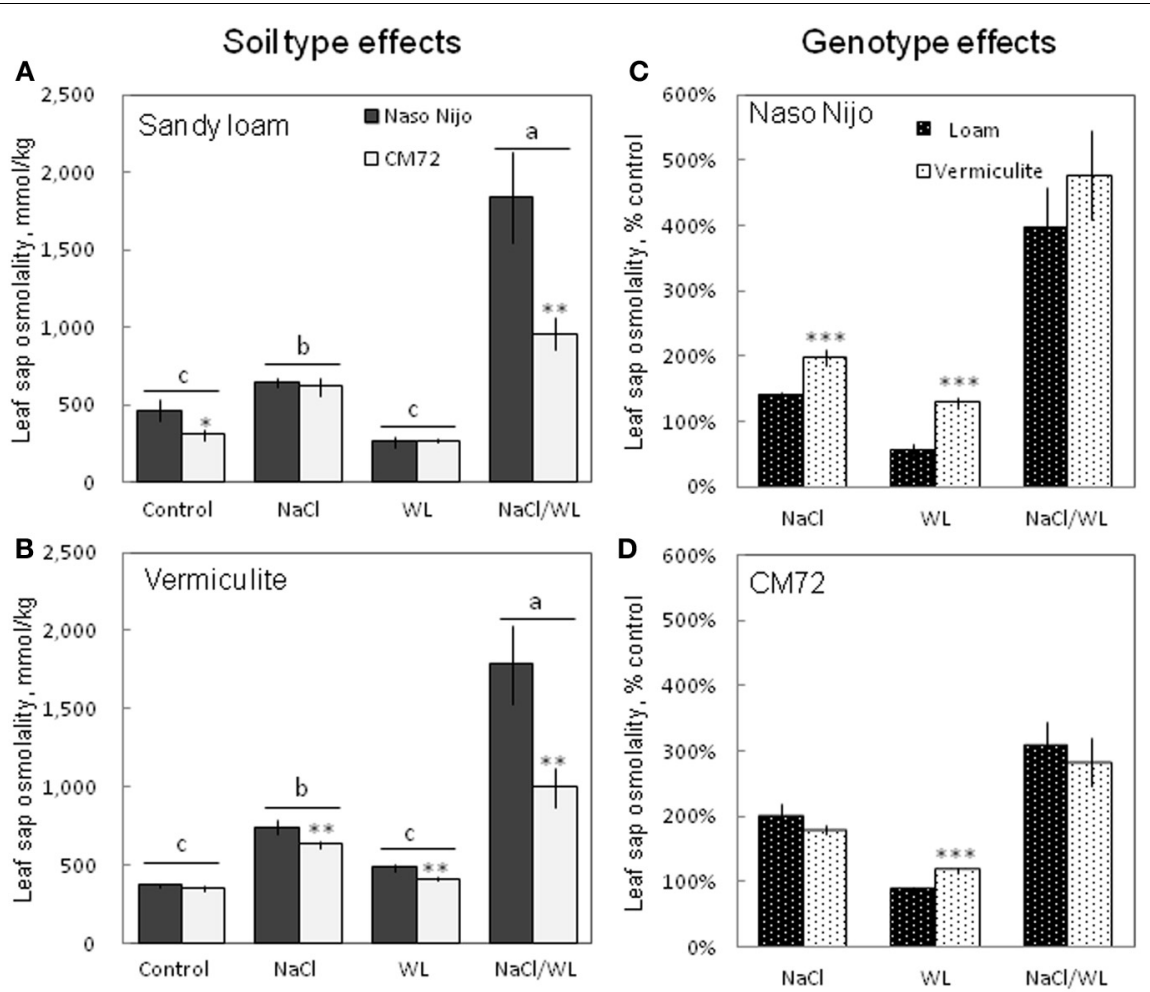

FIGURE 7 | Effects of separate and combined salinity and waterlogging stresses on leaf sap osmolality of two contrasting barley cultivars.

(A,B) Soil type effects. Dark bars, Naso Nijo; light bars, CM72. (C,D) Genotype effects. Dark bars, sandy loam; light bars, vermiculite. For growth conditions, details of treatments, and media composition, refer to the Materials and Methods section. Mean \pm SD $(n=5)$. Different lower case letters indicate the significant difference between treatments (averaged for both genotypes) at $P<0.01$. Asterisks indicate the significant difference between cultivars within the treatment at ${ }^{*} P<0.01$, ** $P<0.001$ and $* * * P<0.0001$.

\section{ROOT ATP CONTENT}

Under normoxic conditions, the ATP content in plant roots was not significantly (at $P<0.05$ ) different between genotypes (Figure 10). ATP content was also not significantly (at $P<0.05$ ) different between two soil types, ranging from 42 to $51 \mathrm{nmol}$ $\mathrm{ATP} / \mathrm{g}$ FW (Figure 10). Two weeks of hypoxia resulted in a 2-3-fold decrease in the root ATP content. No significant $(P<$ 0.05) effect of soil type on ATP decline was observed (Figure 10). Hypoxia-exposed CM72 plants were capable of maintaining a slightly higher (significant at $P<0.05$ ) root ATP level compared with Naso Nijo variety.

\section{CHANGES IN SOIL CHEMISTRY}

Development of hypoxia was accompanied by a progressive decline in the soil redox potential (ORP), from $391 \pm$ $1.5 \mathrm{mV}$ to less than $50 \mathrm{mV}$, depending on the soil type and duration of waterlogging (Figure 11). No significant (at $P<$ 0.05) differences were found for the ORP values between two soil types after 3 days of WL stress. When pots were submerged for 2 weeks however, ORP values were significantly $(P<0.01)$ lower in sandy loam compared with vermiculite ( $80 \pm 4.4 \mathrm{mV}$ vs. $151 \pm 4.5 \mathrm{mV}$, respectively). The presence of salt further reduced the appropriate ORP values for each treatment by $30-40 \mathrm{mV}$, but the general trends remained the same.
Consistent with the decline in the ORP values, waterlogging induced a very substantial increase in both $\mathrm{Mn}$ and $\mathrm{Fe}$ content in the sandy loam soil (Figure 12). After 2 weeks of waterlogging, the $\mathrm{Mn}$ content rose from $2.8 \pm$ 0.01 to $15.4 \pm 0.06 \mathrm{ppm}$ in waterlogging treatment alone, and to $21.8 \pm 0.08 \mathrm{ppm}$ in combined $\mathrm{NaCl} / \mathrm{WL}$ treatment, exceeding the threshold level considered to be toxic for cereals (10 ppm; Setter et al., 2009; shown as a dotted line). Also dramatic was the increase in solution $\mathrm{Fe}$ content (from $0.23 \pm 0.02 \mathrm{ppm}$ to $16.8 \pm 0.05 \mathrm{ppm}$ ). No physiologically relevant increase in either $\mathrm{Mn}$ or $\mathrm{Fe}$ content was found in waterlogged vermiculite (Figure 12). The presence of $\mathrm{NaCl}$ in the media consistently increased the $\mathrm{Mn}$ and $\mathrm{Fe}$ content in the soil solution by around 2-fold for each treatment.

\section{ROOT ION FLUX CHANGES}

A strong net $\mathrm{K}^{+}$uptake of $130-180 \mathrm{nmol} \mathrm{m} \mathrm{m}^{-2} \mathrm{~s}^{-1}$ (depending on gentotype) was measured from the barley root epidermis in the control (Figure 13A). After 1 days of root treatment with $1 \mathrm{mM} \mathrm{Mn}, \mathrm{K}^{+}$fluxes turned to a net efflux of $35-70 \mathrm{~m}^{-2} \mathrm{~s}^{-1}$ and remained negative (net $\mathrm{K}^{+}$loss) for at least a few more days (Figure 13A). This Mn-induced $\mathrm{K}^{+}$efflux was 2-fold higher in the waterlogging-sensitive Naso Nojo variety (significant at $P<0.05$ ). Changes in $\mathrm{H}^{+}$ 

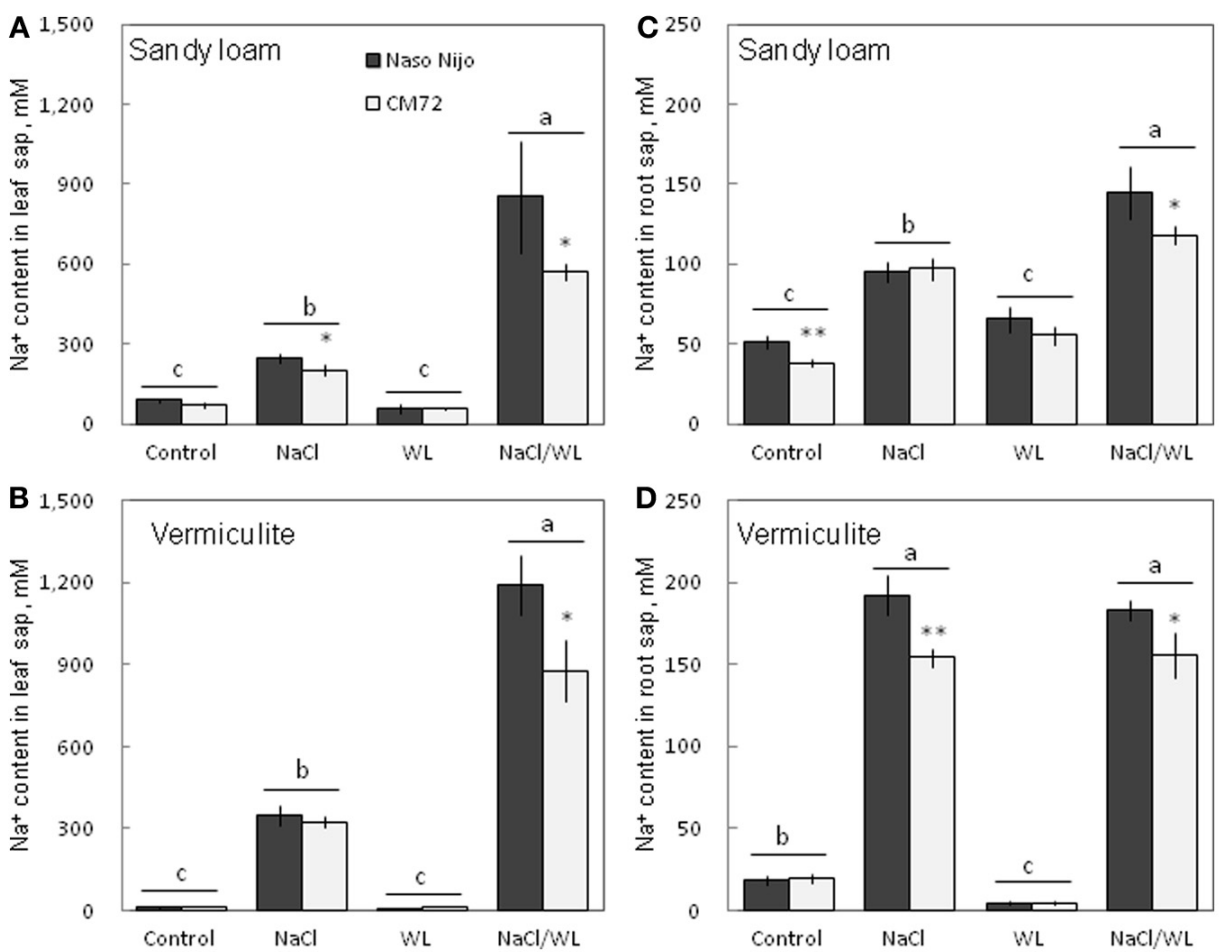

FIGURE 8 | Effects of separate and combined salinity and waterlogging stresses on tissue $\mathrm{Na}^{+}$content of two contrasting barley cultivars. (A,B) Soil type effects. Dark bars, Naso Nijo; light bars, CM72. (C,D) Genotype effects. Dark bars, sandy loam; light bars, vermiculite. For growth conditions, details of treatments, and media

composition, refer to the Materials and Methods section. Mean $\pm S D$ $(n=5)$. Different lower case letters indicate the significant difference between treatments (averaged for both genotypes) at $P<0.01$. Asterisks indicate the significant difference between cultivars within treatment at $* P<0.01,{ }^{* *} P<0.001$.

flux mirrored the changes in the $\mathrm{K}^{+}$flux. A strong net $\mathrm{H}^{+}$efflux of around $50 \mathrm{nmol} \mathrm{m} \mathrm{m}^{-2} \mathrm{~s}^{-1}$ was measured from the control roots (Figure 13B). This efflux was sensitive to $1 \mathrm{mM}$ vanadate, a known blocker of $\mathrm{H}^{+}$-ATPase (data not shown). Mn treatment reversed the $\mathrm{H}^{+}$efflux into a net $\mathrm{H}^{+}$influx after 1 day (Figure 13B). At day 3 of $\mathrm{Mn}$ treatment, the CM72 genotype was capable of restoring its net $\mathrm{H}^{+}$extrusion (albeit at a reduced rate), while the WLsensitive variety Naso Nijo still displayed a net $\mathrm{H}^{+}$influx (Figure 13B).

\section{DISCUSSION \\ DISTURBANCE TO $\mathrm{K}^{+} / \mathrm{NA}^{+}$HOMEOSTASIS IS CENTRAL FOR THE SEVERE EFFECTS OF COMBINED SALINITY AND WATERLOGGING STRESS}

In this study, a much more dramatic increase in $\mathrm{Na}^{+}$and decrease in $\mathrm{K}^{+}$content were observed in both roots and leaves of barley plants grown under a combined salinity and waterlogging stress compared to plants grown with salinity under drained condition (Figures 8, 9). Intracellular $\mathrm{K}^{+} / \mathrm{Na}^{+}$homeostasis is often named as a key determinant of plant salinity tolerance (Maathuis and Amtmann, 1999; Shabala and Cuin, 2008). The key players in this process are the plasma membrane SOS1 $\mathrm{Na}^{+} / \mathrm{H}^{+}$antiporters that actively expel $\mathrm{Na}^{+}$ from the cytosol (Shi et al., 2002) and depolarization-activated outward-rectifying (GORK in Arabidopsis; Ache et al., 2000) channels, responsible for $\mathrm{K}^{+}$retention in the cytosol (Shabala and Cuin, 2008). The operation of both of these transporters is critically dependent on oxygen availability. Indeed, SOS1 activity relies on existence of steep $\mathrm{H}^{+}$gradients across the plasma membrane, fueled by the plasma membrane $\mathrm{H}^{+}$ATPase activity (Palmgren and Harper, 1999). The $\mathrm{H}^{+}$-pump is also the main electrogenic factor essential for maintaining a highly negative membrane potential value, thus keeping GORK channels closed. Salinity by itself causes a substantial membrane depolarization (by $60-80 \mathrm{mV}$; Shabala and Cuin, 2008). As the oxygen is gradually used up (under waterlogged conditions), root $\mathrm{O}_{2}$ deficiency would restrict aerobic respiration, so the production of ATP would be dramatically reduced (from 30 to $36 \mathrm{~mol}$ ATP via mitochondrial oxidative phosphorylation to 2-4 mol ATP via glycolysis per hexose, BaileySerres and Voesenek, 2008). Indeed, the ATP content dropped 2-3-fold in waterlogging-affected roots (Figure 10). This reduction will compromise a plant's ability to fuel $\mathrm{H}^{+}$-ATPases, with major implications to both $\mathrm{Na}^{+}$exclusion and $\mathrm{K}^{+}$retention, as discussed above. Overall, unfavorable $\mathrm{Na}^{+} / \mathrm{K}^{+}$ratios in plant will affect plant metabolism, resulting in a significant decrease in chlorophyll content (Figure 3) and photochemical efficiency of PSII (Figure 4); drastic increases in the number of chlorotic and necrotic leaves (Figure 5) and leaf sap osmolality 

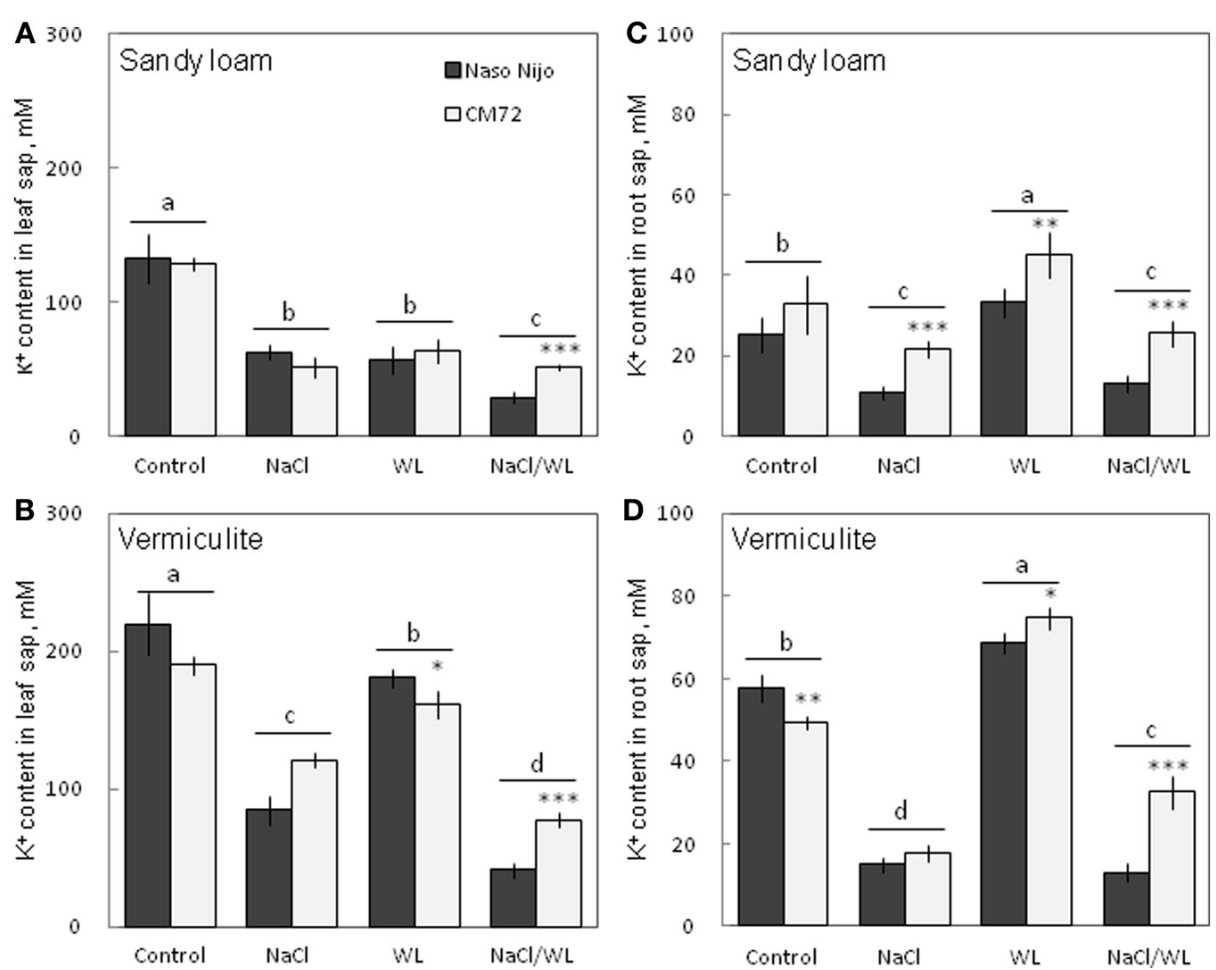

FIGURE 9 | Effects of separate and combined salinity and waterlogging stresses on tissue $\mathrm{K}^{+}$content of two contrasting barley cultivars. (A,B) Soil type effects. Dark bars, Naso Nijo; light bars, CM72. (C,D) Genotype effects. Dark bars, sandy loam; light bars, vermiculite. For growth conditions, details of treatments, and media

(Figure 7); and ultimately reduced growth of roots and shoots (Figures 1, 2).

\section{SOIL TYPE AFFECTS THE ADVERSE EFFECTS OF COMBINED WATERLOGGING AND SALINITY STRESS}

As the soil redox potential is reduced under waterlogged conditions, manganese dioxide $\left(\mathrm{Mn}^{4+}\right)$ and the insoluble ferric $\left(\mathrm{Fe}^{3+}\right)$ hydroxides are reduced to the soluble manganous $\left(\mathrm{Mn}^{2+}\right)$ and ferrous $\left(\mathrm{Fe}^{2+}\right)$ ions (Khabaz-Saberi et al., 2006; Setter et al., 2009; Hernandez-Soriano et al., 2012). In our case, a substantial increase in both $\mathrm{Mn}$ and $\mathrm{Fe}$ content in the soil solution was observed for the sandy loam, but not the vermiculite soil (Figure 12). Despite its importance as an essential micronutrient, excess $\mathrm{Mn}$ is damaging to the photosynthetic apparatus, interferes with uptake of other nutrients and may cause oxidative stress, resulting in chlorosis and necrosis in leaves and subsequently death of whole plants (Millaleo et al., 2010). Visual symptoms of Mn toxicity such as chlorosis and necrosis were observed in barley leaves of hydroponicallygrown plants at concentrations as low as $50 \mu \mathrm{M}$ (i.e., $<5 \mathrm{ppm}$; Führs et al., 2010). In field experiments, the toxic threshold for cereals grown in drained soils was reported to be around $10 \mathrm{ppm}$ of $\mathrm{Mn}$ (Setter et al., 2009). In our case, the Mn content in the sandy loam soil solution exceeded the latter threshold by day 14 for WL alone treatment, and was composition, refer to the Materials and Methods section. Mean \pm SD $(n=5)$. Different lower case letters indicate the significant difference between treatments (averaged for both genotypes) at $P<0.01$. Asterisks indicate the significant difference between cultivars within treatment at $* P<0.01$, ** $P<0.001$, and $* * * P<0.0001$.

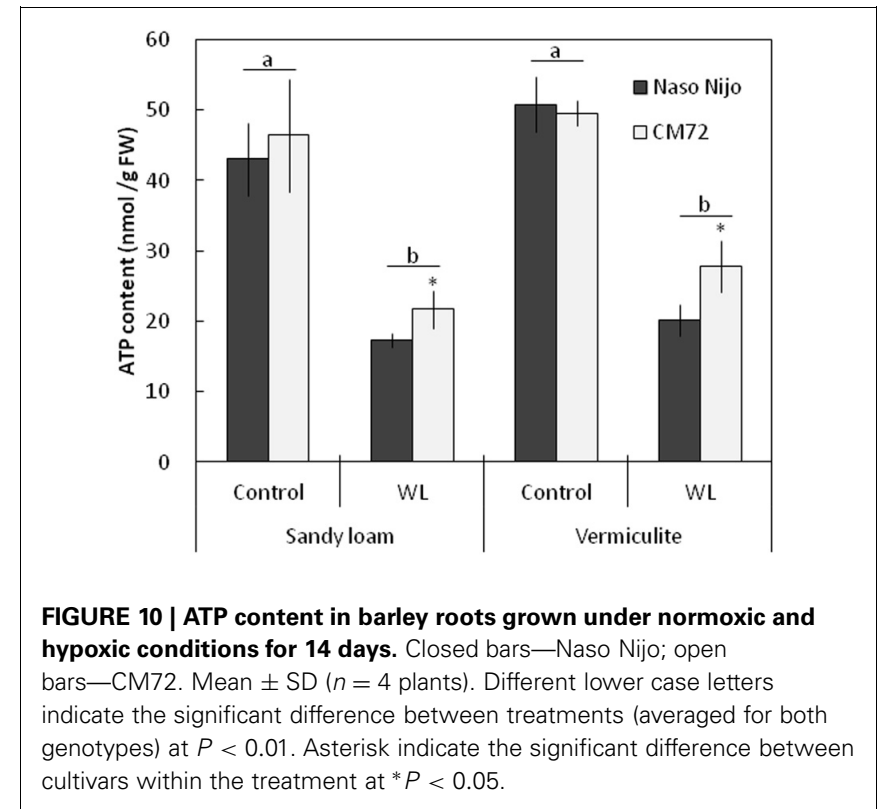

close to it around day 3 in the combined $\mathrm{NaCl} / \mathrm{WL}$ treatment (Figure 12). Mn treatment also had major implications for $\mathrm{K}^{+}$ retention in barley roots within $24 \mathrm{~h}$ of exposure (Figure 13). Consequently, the dramatic increase in Mn concentration that 


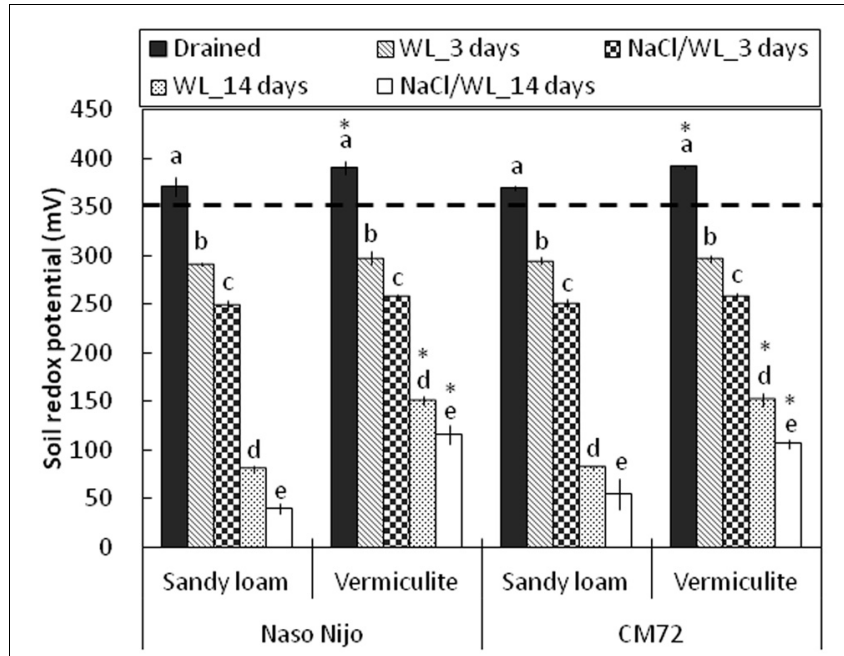

FIGURE 11 | Soil redox potential during waterlogging (submerged; no $\mathrm{NaCl}$ ) and combined salinity and waterlogging (submerged in $200 \mathrm{mM}$ $\mathrm{NaCl}$ solution) treatments. Soil redox potential measurements were taken before treatment (drained), and 3 days and 14 days after commencing the treatments. Mean $\pm \mathrm{SD}(n=5)$. Different lower case letters indicate the significant difference between treatments within soil type at $P<0.01$. Asterisk indicates the significant differences between sandy loam and vermiculite within variety a $P<0.01$. Horizontal dashed line indicates the threshold level for anaerobic condition (below $350 \mathrm{mV}$ )

we found in sandy loam (up to $20 \mathrm{ppm}$, Figure 12) under waterlogged conditions would likely induce a high risk of Mn toxicity to barley plants. Interestingly, the presence of $\mathrm{NaCl}$ in the soil exacerbated the effect of waterlogging on Mn availability, in a full agreement with the ORP data (Figure 11). The Fe content in the soil solution also increased steadily, approaching toxic levels. Together, when delivered to the shoot by the transpiration flow, these two toxic micronutrients could lead to increased ROS formation in green tissues (Millaleo et al., 2010; Keunen et al., 2011), impairing the photosynthetic machinery (Figure 4), reducing chlorophyll content (Figure 3) and enhancing the senescence process (Figure 5). Such elemental toxicity may be an additional (to unfavorable $\mathrm{Na}^{+} / \mathrm{K}^{+}$balance in leaf tissues) factor contributing to the poor plant performance under combined $\mathrm{WL} / \mathrm{NaCl}$ conditions in sandy loam. Elemental toxicity, however, is not a factor for vermiculate-grown plants, explaining their much better performance (compared with loam-grown plants) under combined stress conditions (Figures 1, 2).

So far, most studies dealing with the combined effects of salinity and waterlogging stress have been conducted with deoxygenated solution (stagnant agar solution or $\mathrm{N}_{2}$ aerated solution) or waterlogged sand (Barrett-Lennard, 2003; Teakle et al., 2006, 2010; Rogers et al., 2011). Being very useful to clarify the underlying mechanisms of this interaction, these results may be at some discrepancy with the real situation in the natural stressed environment, due to the lack of the factor of elemental toxicity, typically present in waterlogged soils. Therefore, for accurately evaluating and efficiently improving the tolerance of germplasm to combined salinity and waterlogging stress, it is
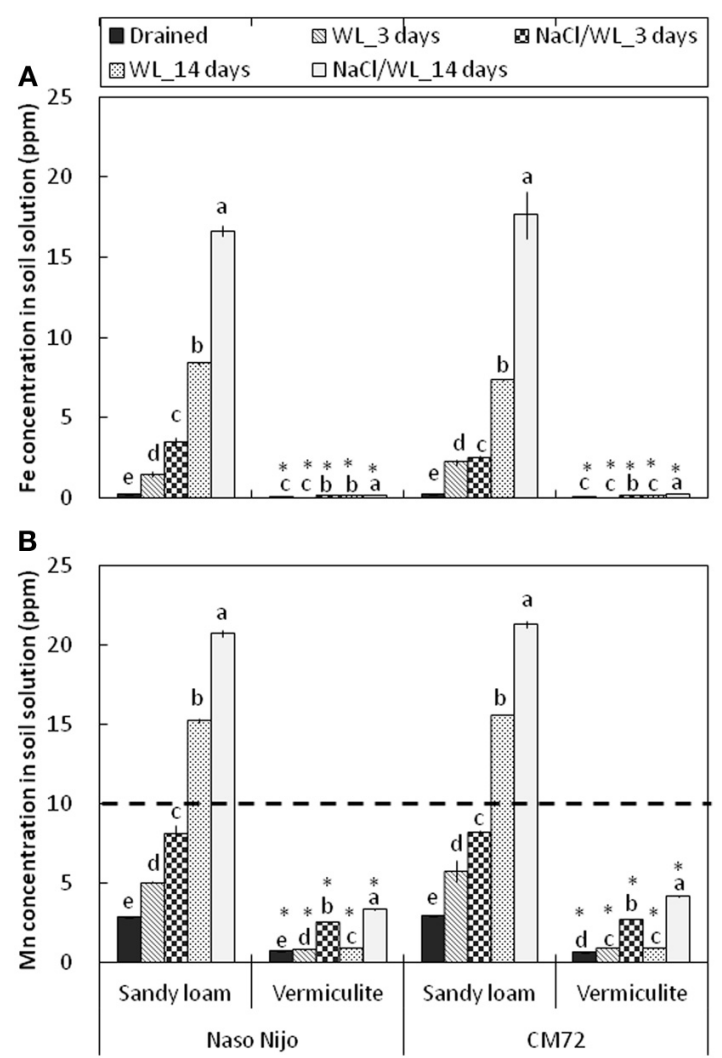

FIGURE 12 | Concentrations of $\mathrm{Fe}(\mathrm{A})$ and $\mathrm{Mn}(\mathrm{B})$ in the soil solution in pots subjected to waterlogging (submerged; no $\mathrm{NaCl}$ ) and combined salinity and waterlogging (submerged in $200 \mathrm{mM} \mathrm{NaCl}$ solution). Soil samples were taken on days 3 and 14 since commencement of treatment and compared with those taken from control treatment. Mean $\pm \mathrm{SD}$ $(n=5)$. Different lower case letters indicate the significant difference within the soil type at $P<0.01$. Asterisk indicates the significant differences between sandy loam and vermiculite within variety at $P<0.01$.

necessary to carry out investigations and screening with the soil from the target environment rather than with artificial growing methods.

\section{GENOTYPIC DIFFERENCES IN RESPONDING TO COMBINED WATERLOGGING AND SALINITY STRESS AND THEIR POTENTIAL UTILIZATION IN SALTLAND}

It is estimated that over 370,000 barley germplasms are preserved as ex situ collections in worldwide representative genebanks (Saisho and Takeda, 2011). The genetic diversity of either salinity or waterlogging tolerance has been well proved amongst cultivated and even wild barley germplasms (Wu et al., 2011). However, little information about the genetic variation in a combined waterlogging and salinity stress has been accumulated. In the present study, a significant genetic difference in response to combined waterlogging and salinity stress was observed between CM72 and Naso Nijo. Regardless of the soil type, CM72 showed a much higher tolerance to combined $\mathrm{WL} / \mathrm{NaCl}$ stress than Naso Nijo, as reflected by the lower reduction in root and shoot growth (Figures 1, 2), higher chlorophyll content (Figure 3) 


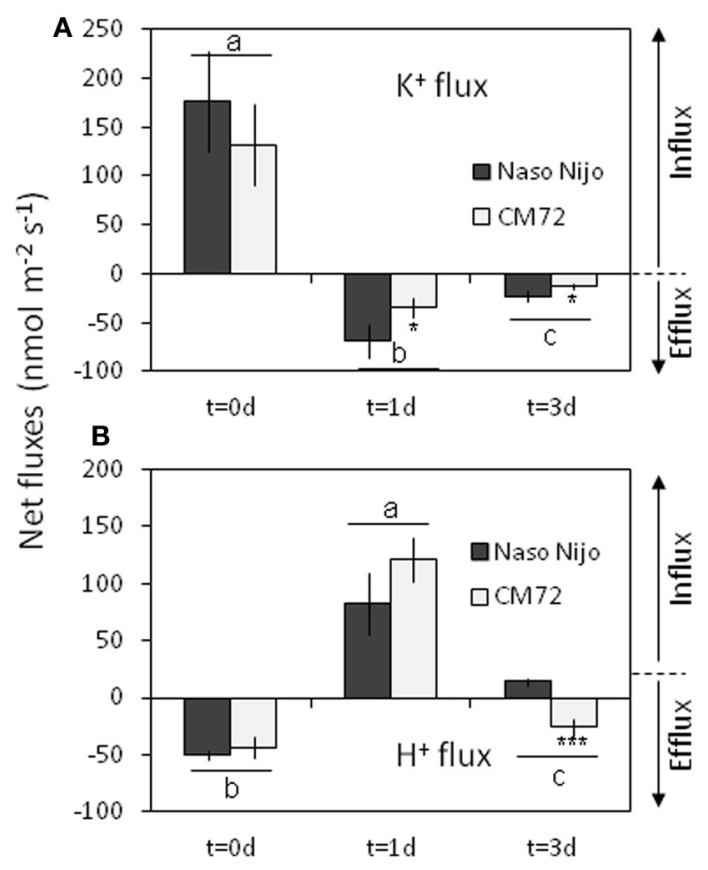

FIGURE 13 | Net steady-state $\mathrm{K}^{+}(\mathrm{A})$ and $\mathrm{H}^{+}(\mathrm{B})$ fluxes measured from mature barley root epidermis in control (day 0 ) and after one and three days exposure to $\mathbf{1} \mathbf{~ m M ~ M n . ~ M e a n ~} \pm S D(n=6)$. Different lower case letters indicate the significant difference between treatments (averaged for both genotypes) at $P<0.05$. Asterisks indicate the significant difference between cultivars within treatment at ${ }^{*} P<0.05$ and ${ }^{* * *} P<0.001$.

\section{REFERENCES}

Ache, P., Becker, D., Ivashikina, N., Dietrich, P., Roelfsema, M. R. G., and Hedrich, R. (2000). GORK, a delayed outward rectifier expressed in guard cells of Arabidopsis thaliana, is a $\mathrm{K}^{+}$-selective, $\mathrm{K}^{+}$-sensing ion channel. FEBS Lett. 486, 93-98. doi: 10.1016/S0014-5793(00)02248-1

Bailey-Serres, J., and Voesenek, L. A. C. J. (2008). Flooding stress: acclimations and genetic diversity. Ann. Rev. Plant Biol. 59, 313-339. doi: 10.1146/annurev.arplant.59. 032607.092752

Barrett-Lennard, E. G. (2003). The interaction between waterlogging and salinity in higher plants: causes, consequences and implications. Plant Soil 253, 35-54. doi: 10.1023/A:1024574622669

Bennett, S. J., Barrett-Lennard, E. G., and Colmer, T. D. (2009). Salinity and waterlogging as constraints to saltland pasture production: a review. Agri. Eco. Environ. 129, 349-360. doi: 10.1016/j.agee.2008.10.013

Carter, J. L., Colmer, T. D., and Veneklaas, E. J. (2006). Variable tolerance of wetland tree species to combined salinity and waterlogging is related to regulation of ion uptake and production of organic solutes. New Phytol. 169, 123-134. doi: 10.1111/j.1469-8137.2005.01552.x

Chen, Z., Zhou, M., Newman, I., Mendham, N., Zhang, G., and Shabala, S. (2007). Potassium and sodium relations in salinised barley tissues as a basis of differential salt tolerance. Funct. Plant Biol. 34, 150-162. doi: 10.1071/FP06237

Cuin, T. A., Betts, S. A., Chalmandrier, R., and Shabala, S. (2008). A root's ability to retain $\mathrm{K}^{+}$correlates with salt tolerance in wheat. J. Exp. Bot. 59, 2697-2706. doi: 10.1093/jxb/ern 128

FAO. (2008). FAO Land and Plant Nutrition Management Service. Available online at: http://www.fao. org/ag/agl/agll/spush

Führs, H., Behrens, C., Gallien, S., Heintz, D., Van Dorsselaer, A., Braun, H. P., et al. (2010). Physiological and proteomic characterization of manganese sensitivity and tolerance in rice (Oryza sativa) in comparison with barley (Hordeum vulgare). Ann. Bot. 105, 1129-1140. doi: 10.1093/aob/mcq046

Hatton, T. J., Ruprecht, J., and George, R. J. (2003). Preclearing

and fluorescence (Figure 4), fewer chlorotic and necrotic leaves (Figure 5), higher leaf WC (Figure 6), lower $\mathrm{Na}^{+}$, and higher $\mathrm{K}^{+}$content in root and leaf sap (Figures 8, 9). The vast collection of barley germplasms and the recent completion of the barley genome sequencing (The International Barley Genome Sequencing Consortium, 2012) makes it possible to thoroughly explore the potential mechanisms of tolerance of different barley cultivars to individual or combined stress conditions and utilize the more tolerant lines to breed suitable varieties for the corresponding environment. Up to now, saltland agriculture has relied heavily on the use of pasture halophylic species such as Atriplex, Maireana, Puccinellia, Thinopyrum, Lotus, and Melilotus (Teakle et al., 2006; Bennett et al., 2009; Rogers et al., 2011). Barley is a crop that can be used not only for animal feed, but also for alcoholic and non-alcoholic beverages and human food. It is already known for its tolerance to stresses such as cold, drought, and salinity (Saisho and Takeda, 2011). It can be predicted that barley will be a potential food source in future for the increasing world population under deteriorating environments. To achieve this goal, truly tolerant varieties capable of performing without, or with only little yield reduction, under hostile soil conditions, such as combined salinity and waterlogging, should be selected or created by breeders.

\section{ACKNOWLEDGMENTS}

This work was supported by the Australian Research Council Discovery (to Sergey Shabala) and ARC Linkage (to Sergey Shabala, Meixue Zhou, and Lana Shabala) grants.

hydrology of the Western Australia wheatbelt: target for the future. Plant Soil 257, 341-356. doi: 10.1023/A:1027310511299

Hernandez-Soriano, M. C., Degryse, F., Lombi, E., and Smolders, E. (2012). Manganese toxicity in barley is controlled by solution manganese and soil manganese speciation. Soil Sci. Soc. Am. J. 76, 399-407. doi: 10.2136/sssaj2011.0193

Joseph, B., and Jini, D. (2010). Salinity induced programmed cell death in plants: challenges and opportunities for salt-tolerant plants. J. Plant Sci. 5, 376-390. doi 10.3923/jps.2010.376.390

Keunen, E., Remans, T., Bohler, S., Vangronsveld, J., and Cuypers, A. (2011). Metal-induced oxidative stress and plant mitochondria. Int. J. Mol. Sci. 12, 6894-6918. doi: 10.3390/ijms12106894

Khabaz-Saberi, H., Setter, T. L., and Waters, I. (2006). Waterlogging induces high to toxic concentrations of iron, aluminum, and manganese in wheat varieties on acidic soil. J. Plant Nutr. 29, 899-911. doi 10.1080/01904160600649161

Kozlowski, T. T. (1997). Responses of woody plants to flooding and salinity. Tree Physiol. Monograph 1, 1-29.
Maathuis, F. J. M., and Amtmann, A. (1999). $\mathrm{K}^{+}$nutrition and $\mathrm{Na}^{+}$toxicity: the basis of cellular $\mathrm{K}^{+} / \mathrm{Na}^{+}$ ratios. Ann. Bot. 84, 123-133. doi: 10.1006/anbo.1999.0912

Millaleo, R., Reyes-Díaz, M., Ivanov, A. G., Mora, M. L., and Alberdi, M (2010). Manganese as essential and toxic element for plants: transport, accumulation and resistance mechanisms. J. Soil Sci. Plant Nutr. 10, 476-494.

Palmgren, M. G., and Harper, J. F. (1999). Pumping with plant P-type ATPases. J. Exp. Bot. 50, 883-893.

Pang, J., Cuin, T. A., Shabala, L., Zhou, M., Mendham, N., and Shabala, S. (2007). Effect of secondary metabolites associated with anaerobic soil conditions on ion fluxes and electrophysiology in barley roots. Plant Physiol. 145, 266-276. doi: 10.1104/pp.107.102624

Pannell, D. J., and Ewing, M. A. (2004). Managing secondary dryland salinity: options and challenges. Agri. Water Manage. 80, 41-56. doi: 10.1016/j.agwat.2005.07.003

Rogers, M. E., Colmer, T. D., Nichols, P. G. H., Hughes, S. J., Frost, K., Cornwall, D., et al. (2011). Salinity and waterlogging tolerance amongst accessions of messina 
(Melilotus siculus). Crop Pasture Sci. 62, 225-235. doi: 10.1071/CP10270

Saisho, D., and Takeda, K. (2011). Barley: emergence as a new research material of crop science. Plant Cell Physiol. 52, 724-727. doi: 10.1093/pcp/pcr049

Setter, T. L., and Waters, I. (2003). Review of prospects for germplasm improvement for waterlogging tolerance in wheat, barley and oats. Plant Soil 253, 1-34. doi: 10.1023/A:1024573305997

Setter, T. L., Waters, I., Sharma, S. K., Singh, K. N., Kulshreshtha, N., Yaduvanshi, N. P., et al. (2009). Review of wheat improvement for waterlogging tolerance in Australia and India: the importance of anaerobiosis and element toxicities associated with different soils. Ann. Bot. 103, 221-235. doi: $10.1093 / \mathrm{aob} / \mathrm{mcn} 137$

Shabala, S. (2009). Salinity and programmed cell death: unravelling mechanisms for ion specific signaling. J. Exp. Bot. 60, 709-712. doi: 10.1093/jxb/erp013

Shabala, S. (2011). Physiological and cellular aspects of phytotoxicity tolerance in plants: the role of membrane transporters and implications for crop breeding for waterlogging tolerance. New Phytol. 190, 289-298. doi: 10.1111/j.1469-8137.2010.03575.x

Shabala, S., and Cuin, T. A. (2008). Potassium transport and plant salt tolerance. Physiol. Plant. 133, 651-669. doi: 10.1111/j.1399-3054.2007.01008.x

Shi, H., Quintero, F. J., Pardo, J. M., and Zhu, J. K. (2002). The putative plasma membrane $\mathrm{Na}^{+} / \mathrm{H}^{+}$ antiporter SOS1 controls longdistance $\mathrm{Na}^{+}$transport in plants. Plant Cell 14, 465-477. doi: 10.1105/tpc.010371

Smedema, L. K., and Shiati, K. (2002). Irrigation and salinity: a perspective review of the salinity hazards of irrigation development in the arid zone. Irrig. Drain. Systems 16, 161-174. doi: 10.1023/A:1016008417327

Tanou, G., Molassiotis, A., and Diamantidis, G. (2009). Induction of reactive oxygen species and necrotic death-like destruction in strawberry leaves by salinity. Environ. Exp. Bot. 65, 270-281. doi: 10.1016/j.envexpbot.2008.09.005

Teakle, N. L., Amtmann, A., Real, D., and Colmer, T. D. (2010). Lotus tenuis tolerates combined salinity and waterlogging: maintaining $\mathrm{O}_{2}$ transport to roots and expression of an NHX1-like gene contribute to regulation of $\mathrm{Na}^{+}$transport. Physiol. Plant. 139, 358-374.

Teakle, N. L., Real, D., and Colmer, T. D. (2006). Growth and ion relations in response to combined salinity and waterlogging in the perennial forage legumes Lotus corniculatus and Lotus tenuis. Plant Soil 289,
369-383. doi: 10.1007/s11104-006 9146-8

The International Barley Genome Sequencing Consortium. (2012). A physical, genetic and functional sequence assembly of the barley genome. Nature 491, 711-716.

Wu, D., Qiu, L., Xu, L., Ye, L., Chen, M., Sun, D., et al. (2011). Genetic variation of HvCBF genes and their association with salinity tolerance in tibetan annual wild barley. PLoS ONE 6:e22938. doi: 10.1371/journal.pone.0022938

Xie, Y., Xu, S., Han, B., Wu, M., Yuan, X., Han, Y., et al. (2011) Evidence of Arabidopsis salt acclimation induced by up-regulation of HY1 and the regulatory role of RbohD-derived reactive oxygen species synthesis. Plant J. 66, 280-292. doi: 10.1111/j.1365-313X. 2011.04488.x

Yang, N. C., Ho, W. M., Chen, Y. H., and $\mathrm{Hu}, \mathrm{M}$. L. (2002). A convenient one-step extraction of cellular ATP using boiling water for the luciferin-luciferase assay of ATP. Ana. Biochem. 306, 323-327. doi: 10.1006/abio 2002.5698

Zhou, M. X., Johnson, P., Zhoua, G. F., Li, C. D., and Lance, R. (2012) Quantitative trait loci for waterlogging tolerance in a barley cross of Franklin $\times$ YuYaoXiangTian Erleng and the relationship between waterlogging and salinity tolerance. Crop Sci. 52, 2082-2088. doi: 10.2135/cropsci2012.01.0008

Conflict of Interest Statement: The authors declare that the research was conducted in the absence of any commercial or financial relationships that could be construed as a potential conflict of interest.

Received: 25 February 2013; accepted: 25 July 2013; published online: 14 August 2013.

Citation: Zeng F, Shabala L, Zhou M, Zhang $G$ and Shabala S (2013) Barley responses to combined waterlogging and salinity stress: separating effects of oxygen deprivation and elemental toxicity. Front. Plant Sci. 4:313. doi: 10.3389/fpls. 2013.00313

This article was submitted to Frontiers in Plant Physiology, a specialty of Frontiers in Plant Science.

Copyright (C) 2013 Zeng, Shabala, Zhou, Zhang and Shabala. This is an openaccess article distributed under the terms of the Creative Commons Attribution License (CC BY). The use, distribution or reproduction in other forums is permitted, provided the original author(s) or licensor are credited and that the original publication in this journal is cited, in accordance with accepted academic practice. No use, distribution or reproduction is permitted which does not comply with these terms. 